\title{
THE STRUCTURAL CHANGES IN STEEL USING IN POWER INDUSTRY AFTER LONG-TERM OPERATED
}

\author{
Monika GWOŹDZIK
}

\author{
Czestochowa University of Technology, Faculty of Production Engineering and Materials Technology, \\ Institute of Materials Engineering, Czestochowa, Poland, EU, gwozdzik.monika@wip.pcz.pl
}

https://doi.org/10.37904/metal.2019.831

\begin{abstract}
The paper contains results of studies on the formation of oxide layers on 13CrMo4-5 steels long-term operated at an elevated temperature. The studied steels were operated at the temperature of $380{ }^{\circ} \mathrm{C}$ for $130,000 \mathrm{~h}$ (steel 1) and $535{ }^{\circ} \mathrm{C}$ for $230,000 \mathrm{~h}$ (steel 2). X-ray structural examinations (studying the phase composition and crystallite sizes) were carried out and microscope observations using an optical and scanning microscope were performed. The native material chemical composition was analysed by means of emission spark spectroscopy, while that of oxide layers on a scanning microscope (EDS). The obtained test results showed that the steel exploited at a higher temperature and longer time was significantly degraded.
\end{abstract}

Keywords: Oxide layer, 13CrMo4-5, structure, crystallite sizes, elevated temperature

\section{INTRODUCTION}

Material engineering is a widely used scientific field [1-5]. More and more scientific works are related to the oxidation of materials [3-10], mainly metallic materials [7-10]. The problem of corrosion [11-26], especially high-temperature corrosion [7, 17-26] is widely discussed by many scientific centres. Boiler 13CrMo4-5 steel is a material commonly used in the power industry [27-32], is commonly used as steel for superheater tube bundles in biomass fired boilers [30]. High-temperature corrosion in biomass-fired boilers is still an insufficiently investigated phenomenon which causes unplanned shutdown of the installation and, as a result, economic problems [31]. In order to investigate the time-dependent corrosion behaviour of 13CrMo4-5 steel, a newly developed weight loss probe with several fixed parameter settings was used in paper [28]. In addition to these measurements, time-dependent oxidation of this steel in an air atmosphere was investigated in a muffle furnace. Researchers have shown that the dominant corrosion mechanism is highly dependent on prevailing conditions that is steel temperature, flue gas temperature and velocity [28]. This can be either oxidation of steel by gaseous $\mathrm{O}_{2}$ and $\mathrm{H}_{2} \mathrm{O}$, or a combination of oxidation and active oxidation of induced $\mathrm{Cl}$. The aim of this paper was to characterize the oxide layers/deposits formed on 13CrMo4-5 steel, which was operated for a long time at elevated temperatures.

\section{MATERIALS AND EXPERIMENTAL METHODS}

The material studied comprised specimens of $13 \mathrm{CrMo} 4-5$ steel operated at the temperature of $380^{\circ} \mathrm{C}$ during $130,000 \mathrm{~h}$ (steel 1 ) and $535^{\circ} \mathrm{C}$ during $230,000 \mathrm{~h}$ (steel 2). The oxide layer was studied at the inner site (the flowing steam side) on the pipe. Thorough examinations of the oxide layer carried out on the outer surface of tube wall comprised:

- microscopic examination of the studying materials was performed using light microscope (LM) and scanning electron microscope (SEM),

- $\quad$ chemical composition analysis of deposits/oxides using a scanning electron microscope (SEM) working with an EDS electron microprobe X-ray analyser,

- $\quad$ X-ray (XRD) measurements (studying the phase composition, crystallite sizes); Based on the width and the position of the main coat and substrate reflections, the size of the crystallites was determined using 
the Scherrer formula. X-ray studies were carried out on the surface, and then the layer surface was polished down and the diffraction measurements were performed again to determine individual oxide layers. X-ray measurements were carried out, then for each case, the oxide layer was removed $(5 \mu \mathrm{m})$ cyclically, each time making XRD measurements: steel 1 - the oxide layer was removed every $5 \mu \mathrm{m}$ in 6 cycles; steel 2 - the oxide layer was removed every $5 \mu \mathrm{m}$ in 26 cycles. The size of the $D_{h k l}$ crystallites size was determined for the reflections originating from the planes (104) for $\mathrm{Fe}_{2} \mathrm{O}_{3}$ and (311) for $\mathrm{Fe}_{3} \mathrm{O}_{4}$, which are occurring at angles of $38.7464^{\circ}$ and $40.8998^{\circ}$, respectively (according to the catalogue card ICDD PDF 01-079-0007 and ICDD PDF 01-089-0951).

\section{RESULTS OF EXAMINATION}

Microscopic observations of the structure of the steel tested showed (Figure 1) that $13 \mathrm{CrMo} 4-5$ steel operated at a lower temperature $\left(T=380^{\circ} \mathrm{C}\right)$ for a time of 130,000 hours was characterized by a ferritic-bainitic/pearlitic structure (Figure 1a). The longer operating time at a higher temperature caused that the structure of the tested steel was significantly degraded. Figure $1 \mathbf{b}$ shows the ferritic structure with degraded bainite/pearlite and very many carbide precipitates. In the case of steel 2 , the pearlite/bainite has completely disintegrated. In addition, coagulated carbides in a very large form are formed both inside and after grain boundaries. The carbides occurring on the boundaries were combined, forming the so-called chains, and in places there is even the effect of double borders. In addition to carbide precipitations, creep pores are also visible in the structure of this steel.
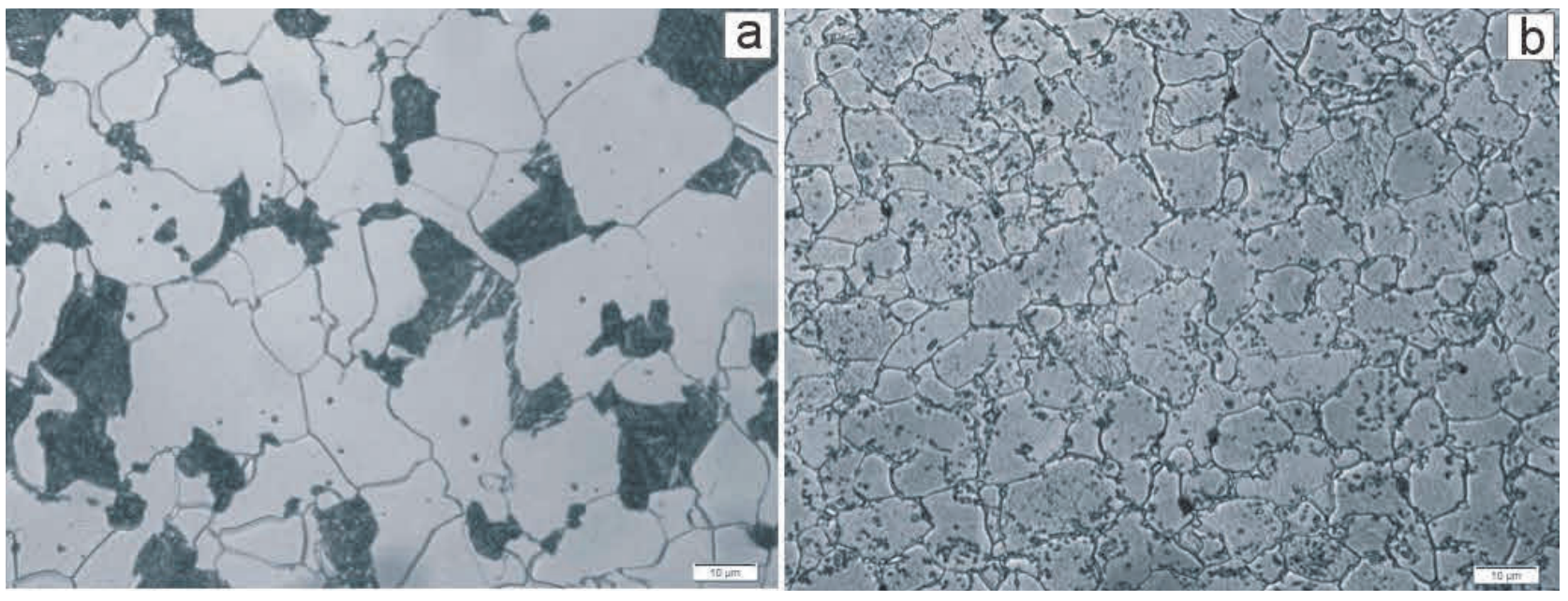

Figure 1 Structure of examined steels: (a) steel 1, (b) steel 2

Microscopic observations (SEM) made on the surface of the oxide layer showed that this layer is more degraded in the case of steel subjected to a higher temperature and a longer time, as shown in Figure 2. The surface of the oxide layer created on steel operated at $535^{\circ} \mathrm{C}$ for a period of 230,000 hours is mostly cracked. The performed chemical analysis from the surface of the pipe walls showed presence oxides iron enriched in the chromium element for both steels (Figure 3). In the case of steel 2, additionally copper deposits appeared. Copper compounds on the inner surface of the power device element (steel 2) and thus in the entire watersteam system are the result of progressive erosion and corrosion processes in supply and condensation systems, where these waters are enriched in trace amounts of copper compounds. In the case of steel 1, the thickness of the oxide layer at the widest area was $32.96 \mu \mathrm{m}$, while for steel 2 the value of this parameter was four times higher and amounted to $137.22 \mu \mathrm{m}$ (Figure 4). In both cases large discontinuities were observed in the oxide layer, however, the oxide layer on steel 2 is characterized by greater degradation. In this steel there are quite large cracks oriented perpendicular to the ground. In addition, this layer exhibits quite numerous slits of relatively large dimensions. 


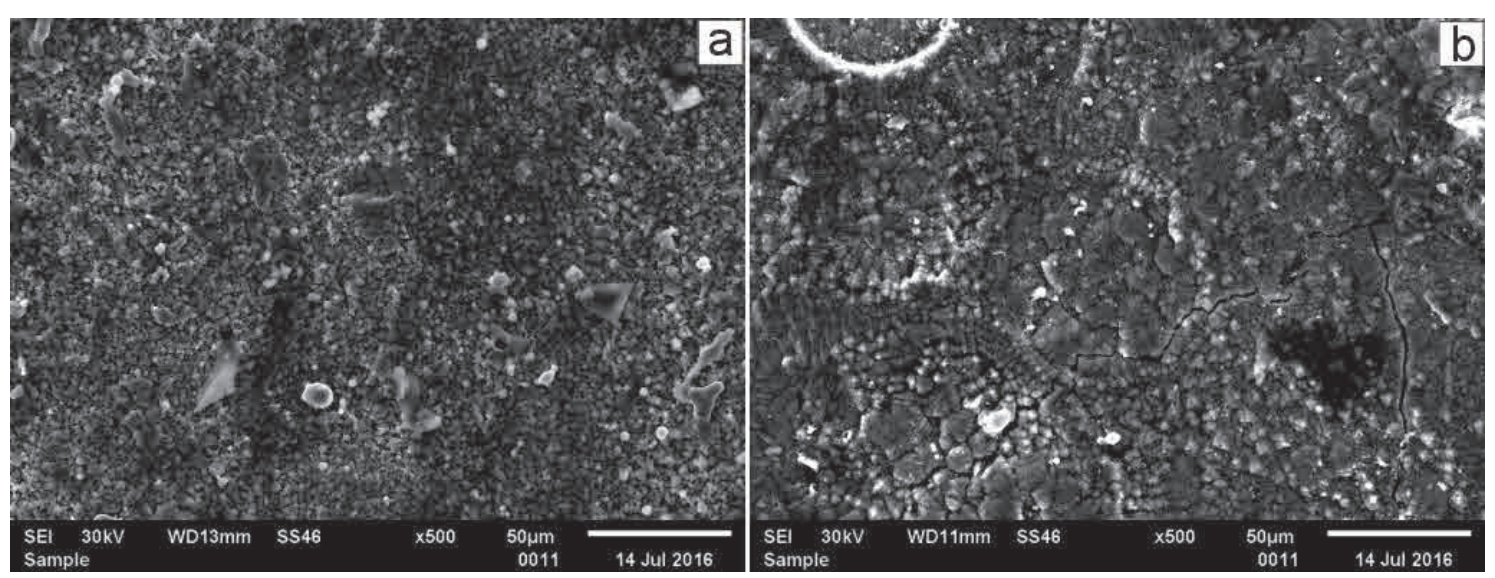

Figure 2 SEM images of the inner site on the pipe: (a) steel 1, (b) steel 2

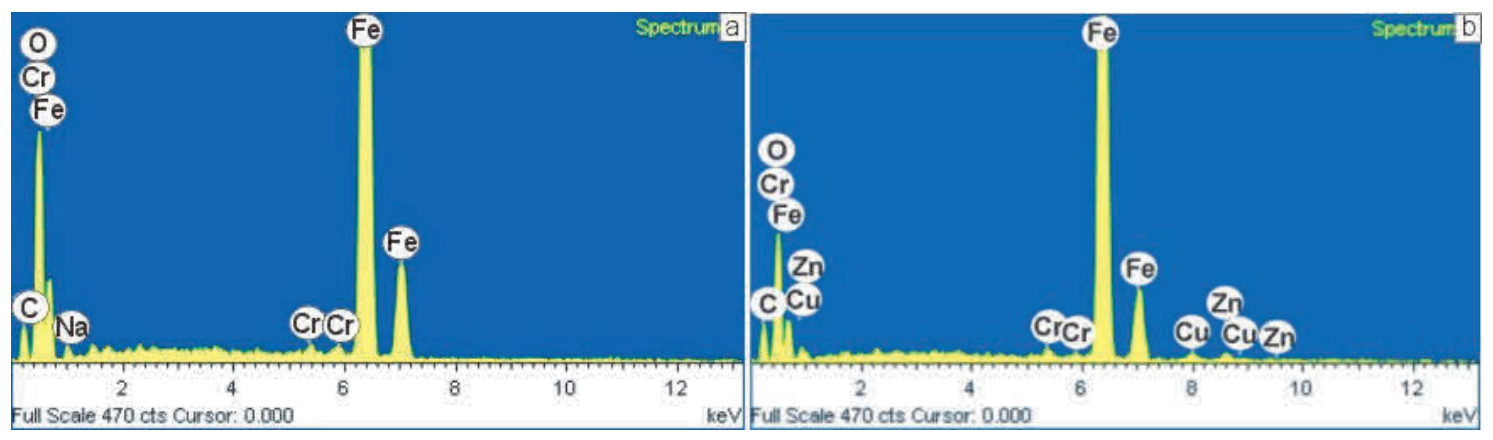

Figure 3 EDS analysis of surface of oxide layer: (a) steel 1, (b) steel 2

In steel 1 under the oxide layer there is decarburization reaching the depth of $120 \mu \mathrm{m}$, while steel 2 on the whole cross-section is characterized by a degraded structure. Surface topography studies showed significant differences in the roughness measurements of the steels tested, as shown in Figure 5. The average arithmetic deviation of the profile from the mean line $(R a)$ was $9.82 \mu \mathrm{m}$ and $23.54 \mu \mathrm{m}$, respectively for steel 1 and 2 . Xray measurements (XRD) showed a two-layered structure of the oxide layer consisting of hematite $\left(\mathrm{Fe}_{2} \mathrm{O}_{3}\right)$ and magnetite $\left(\mathrm{Fe}_{3} \mathrm{O}_{4}\right)$. The application of the method for determining crystallites based on the analysis of the diffraction line profile to the oxide layers formed on steels used in the power industry for a long time allows to determine the relationship between the size of $D_{h k l}$ and the properties of structure on the cross section of the oxide layer.
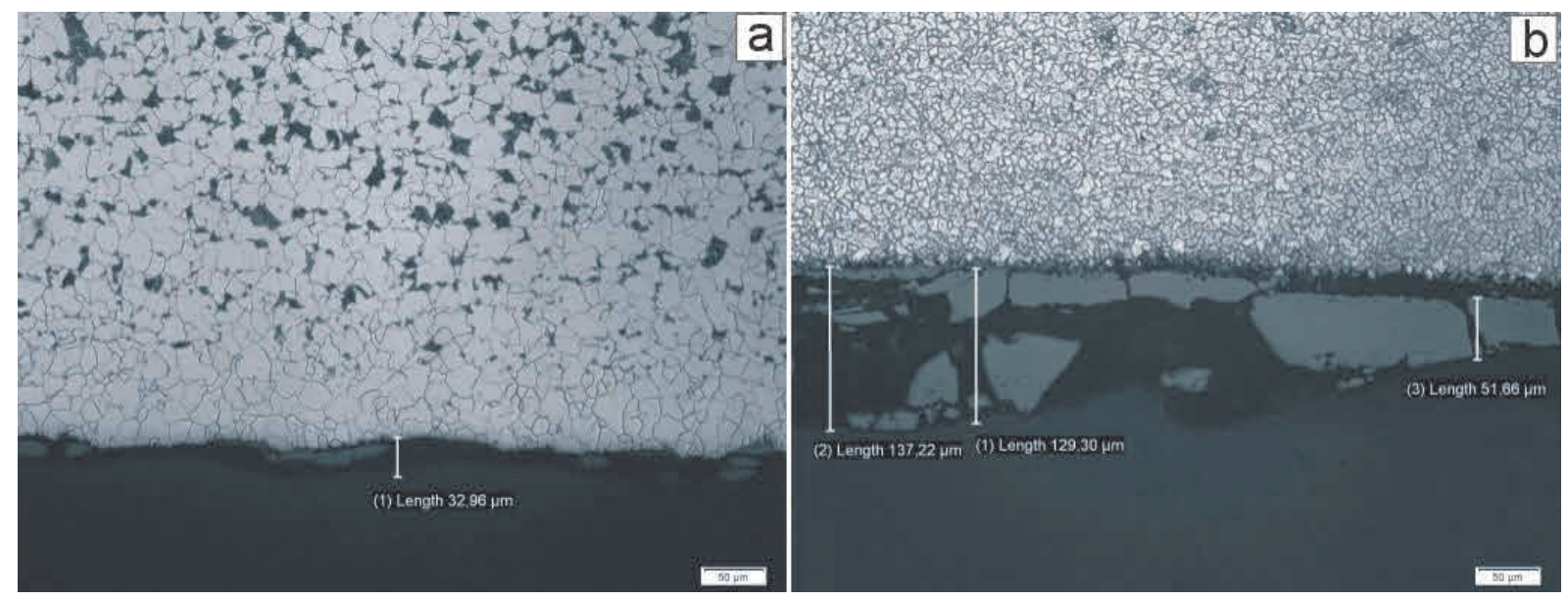

Figure 4 The oxide layers of examined steels: (a) steel 1, (b) steel 2 


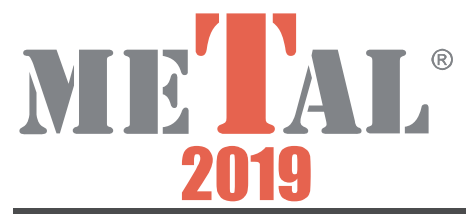

May $22^{\text {nd }}-24^{\text {th }} 2019$, Brno, Czech Republic, EU
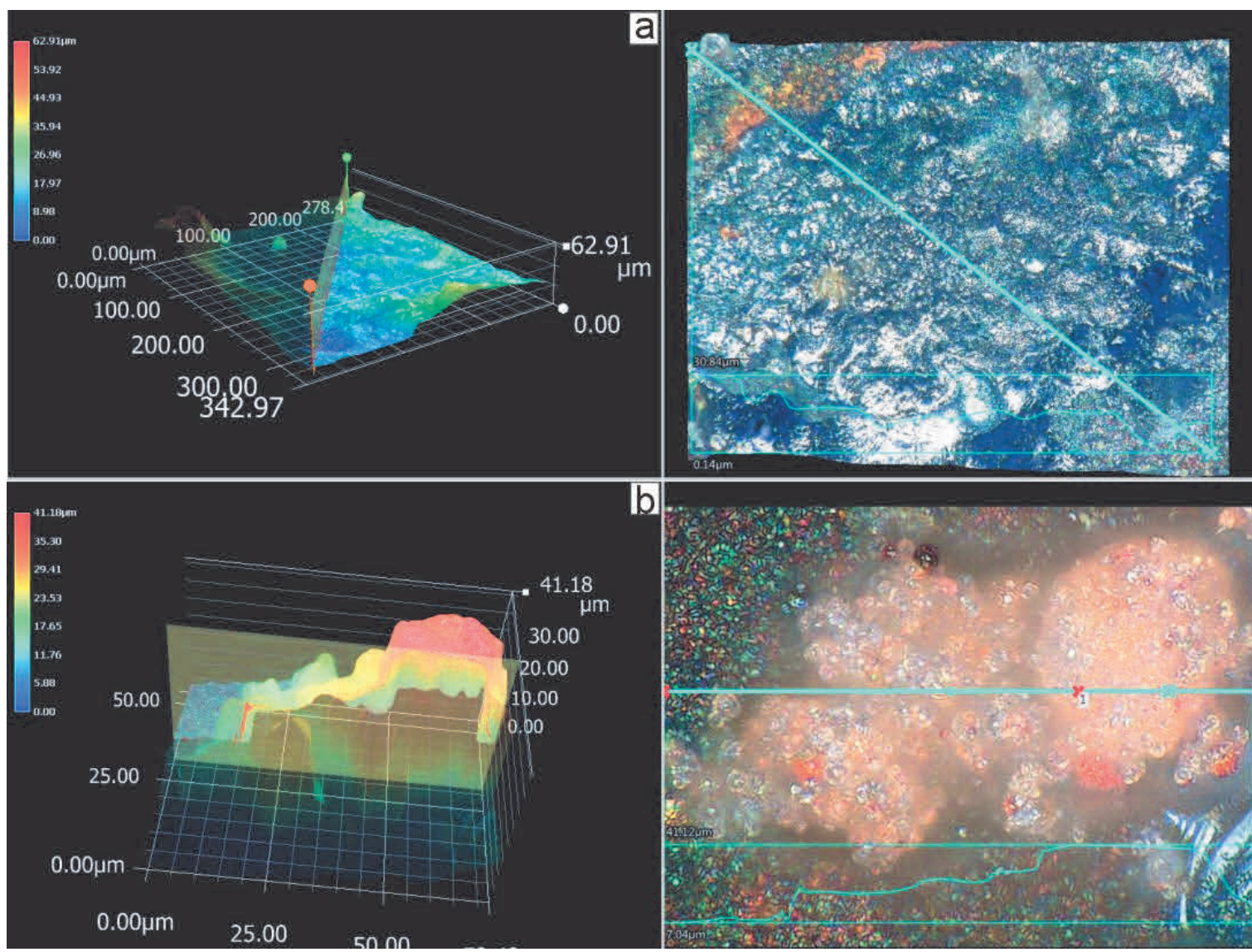

Figure 5 Topography of the surface of the oxide layers studied: (a) steel 1, (b) steel 2

The obtained results showed (Figure 6) that steel 1 was characterized by smaller sizes of crystallites compared to steel 2. For steel 1, the highest value of $D_{h k l}$ for hematite was $42.8 \mathrm{~nm}$, while for magnetite $37.32 \mathrm{~nm}$. In the case of steel 2, $D_{h k l}$ was $43.5 \mathrm{~nm}$ and $38.6 \mathrm{~nm}$ respectively for hematite and magnetite. The results of XRD studies in connection with microscopic observations showed that the crystallite size changes as a function of the distance from the surface. In the case of larger crystallite sizes, the oxide layer is more brittle and prone to cracking. Then cracks form, oxide layers adhere poorly to the substrate, which in turn leads to failure of components operating in the power industry.

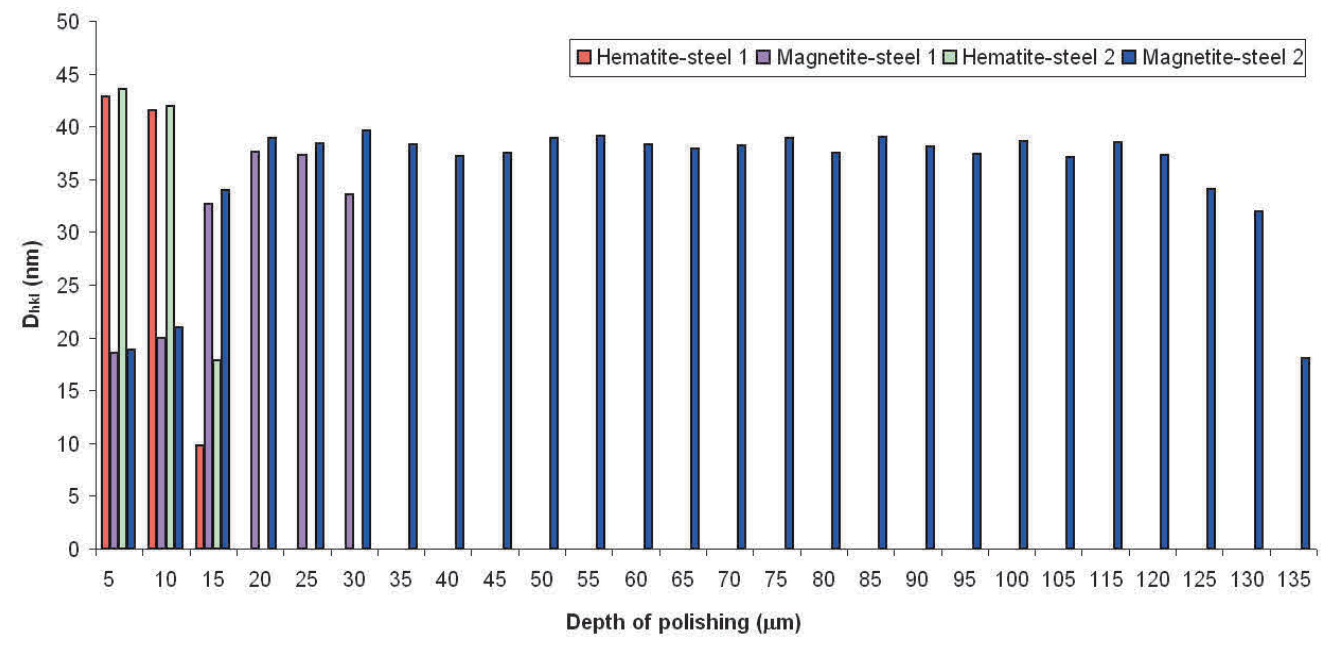

Figure 6 Determination of crystallite size $\left(D_{h k l}\right)$ for main peaks $\mathrm{Fe}_{3} \mathrm{O}_{4}$ and $\mathrm{Fe}_{2} \mathrm{O}_{3}$ 


\section{CONCLUSION}

Based on the conducted research, the following statements and conclusions were formulated:

- $\quad$ higher temperature and longer working time of $13 \mathrm{CrMo} 4-5$ steel leads to a greater degrading of the material structure and the resulting oxide layer;

- the oxide layer which was formed on $13 \mathrm{CrMo4}-5$ steel operated at $\mathrm{T}=535^{\circ} \mathrm{C}$, and $230,000 \mathrm{~h}$ is four times thicker than the oxide layer formed on steel being used $\mathrm{T}=380^{\circ} \mathrm{C}$ and time $130,000 \mathrm{~h}$;

- $\quad$ the roughness parameter $R a$ for steel 2 was more than twice as high as for steel 1 ;

- $\quad$ larger size of crystallites has a negative effect on the durability of the oxide layers.

\section{REFERENCES}

[1] BALAGA, Zbigniew and BIEDAK, Damian, GNATOWSKI, Adam. Examinations of properties and structure of polymer composites with quartz filler. Composites Theory and Practice. 2015. vol. 15, no. 4, pp. 228-232.

[2] BALAGA, Zbigniew, PRZYBYCIN, Anna, WAWRZYNIAK, Jakub and GNATOWSKI, Adam. Examinations of the effect of montmorillonite on selected properties and structure of polybutylene terephthalate. Composites Theory and Practice. 2017. vol. 17, no. 3, pp. 175-179.

[3] PAN, Hong, HUANG, Xiaoxiao, ZHANG, Rui, WANG, Dong, CHEN, Yanting, DUAN, Xiaoming and WEN, Guangwu. Titanium oxide- $\mathrm{Ti}_{3} \mathrm{C}_{2}$ hybrids as sulfur hosts in lithium-sulfur battery: Fast oxidation treatment and enhanced polysulfide adsorption ability. Chemical Engineering Journal. 2019. vol. 358, pp. 1253-1261.

[4] ZHENG, Zhuo, SUN, Weimin and LIU, Zheng. Oxidation behavior of $\mathrm{Al}_{2} \mathrm{O}_{3} / \mathrm{Ti}_{2} \mathrm{AIN}$ composite at high temperature in air. Rare Metal Materials and Engineering. 2019. vol. 47, no. 9, pp. 2717-2722.

[5] NG, Jun Hong, ALMUBARAK, Tariq and NASR-EL-DIN, Hisham A. Low-carbon-steel corrosion at high temperatures by aminopolycarboxylic acids. Spe Production \& Operations. 2018. vol. 33, no. 1, pp. 131-144.

[6] XU, Yang, LUO, Guangqian, PANG, Qicong, HE, Shuangwu, DENG, Fangfang, XU, Yongqing and YAO, Hong. Adsorption and catalytic oxidation of elemental mercury over regenerable magnetic Fe-Ce mixed oxides modified by non-thermal plasma treatment. Chemical Engineering Journal. 2019. vol. 358, pp. 1454-1463.

[7] NIU, Yanqing, TAN, Houzhang and HUI, Shi'en. Ash-related issues during biomass combustion: Alkali-induced slagging, silicate melt-induced slagging (ash fusion), agglomeration, corrosion, ash utilization, and related countermeasures. Progress in Energy and Combustion Science. 2016. vol. 52, pp. 1-61.

[8] ZHOU, Yin, WANG, Shuqi, CHEN, Wei, JIANG, Wei, WANG, Lan, CHEN, Kangmin and CUI Xianghong. Comparative research on the effect of an oxide coating and a tribo-oxide layer on dry sliding wear of Ti-6Al-4V alloy. Proceedings of the Institution of Mechanical Engineers Part J-Journal of Engineering Tribology. 2018. vol. 232, no. 12, pp. 1569-1580.

[9] MOON, Joonho, KIM, Sungyu, PARK, Won Dong, KIM, Tae Yong, MCALPINE, Samuel Westcott, SHORT, Michael, KIM, Ji Hyun and BAHN, Chi Bum. Initial oxidation behavior of Fe-Cr-Si alloys in 1200 degrees C steam. Journal of Nuclear Materials. 2019. vol. 513, pp. 297-308.

[10] ZHONG, Xiangyu, XIA, Shuang, XU, Jan and SHOJI, Tetsuo. The oxidation behavior of 316L in simulated pressurized water reactor environments with cyclically changing concentrations of dissolved oxygen and hydrogen. Journal of Nuclear Materials. 2018. vol. 511, pp. 417-427.

[11] SUMMERS, Kodi L., CHIDAMBARAM, Dev. Corrosion behavior of structural materials for potential use in nitrate salts based solar thermal power plants. Journal of the Electrochemical Society. 2017. vol. 164, no. 8, pp. H5357H5363.

[12] ZHONG, Xiankang, LU, Wenjun, YANG, Huaijun, LIU, Min, ZHANG, Yang, LIU, Hongwei, HU, Junying, ZHANG, Zhi and ZENG, Dezhi. Oxygen corrosion of N80 steel under laboratory conditions simulating high pressure air injection: Analysis of corrosion products. Journal of Petroleum Science and Engineering. 2019. vol. 172, pp. 162170.

[13] KOECH, Pius Kibet and WANG, Chaur Jeng. High-Temperature Corrosion Behaviour of Aluminized-Coated and Uncoated Alloy 718 Under Cyclic Oxidation and Corrosion in $\mathrm{NaCl}$ Vapour at 750 degrees C. Oxidation of Metals. 2018. vol. 90, no. 5-6, pp. 713-735. 
[14] GUO, Xianglong, LAI, Ping, TANG, Lichen, CHEN, Kai and ZHANG, Lefu. Time-dependent wear behavior of alloy 690 tubes fretted against 405 stainless steel in high-temperature argon and water. Wear. 2018. vol. 414, pp. 194201.

[15] CHEN, Jiajun, SONG, Xiping, WANG, Han and LIU, Jingru. Effect of temperature on corrosion behavior of 304 stainless steel in liquid Sn. Rare Metal Materials and Engineering. 2019. vol. 47, no. 9, pp. 2642-2646.

[16] FERNANDEZ, Angel G., MUNOZ-SANCHEZ, Belen, NIETO-MAESTRE, Javier and GARCIA-ROMERO, Ana. High temperature corrosion behavior on molten nitrate salt-based nanofluids for CSP plants. Renewable Energy. 2019. vol. 130, pp. 902-909.

[17] QI, Jing, ZHOU, Keyi, HUANG, Junlin and SI, Xiaodong. Influence of temperature on the oxide spallation of T91 alloy superheater tubes in power plant. Applied Thermal Engineering. 2018. vol. 128, pp. 244-252.

[18] ZHU, Zhiping, QIAO, Yue, WANG, Nana and CAO, Jie. Decomposition characteristics of humic acid in boiler make-up water in power plants. Applied Thermal Engineering. 2018. vol. 128, pp. 1159-1164.

[19] PAN, Ling, XIE, Xuejun, SHEN, Jun, LI, Zhao, WANG, Rui, YANG, Yang and PENG, Keru. Some boiler tubes' crack reason analysis. Progress in Industrial and Civil Engineering II, PTS 1-4. 2013. vol. 405-408, pp. 32533258.

[20] VIDOJKOVIC, Sonja M. and RAKIN, Marco P. Surface properties of magnetite in high temperature aqueous electrolyte solutions: A review. Advanced in Colloid and Interface Science. 2017, vol. 245, pp. 108-129.

[21] AGUERO, Alina, GONZALEZ, Vanessa, MAYR, Peter and SPIRADEK-HAHN, Krystina. Anomalous steam oxidation behavior of a creep resistant martensitic 9 wt. \% Cr steel. Materials Chemistry and Physics. 2013. vol. 141, no. 1, pp. 432-439.

[22] GWOŹDZIK, Monika. The defects of oxide layers formed on 10CrMo9-10 steel operated for 200,000 hours at an elevated temperature. Archives of Metallurgy and Materials. 2016. vol. 61, no. 2, pp. 987-992.

[23] GWOŹDZIK, Monika and NITKIEWICZ, Zygmunt. Texturing of magnetite forming during long-term operation of a pipeline of 10CrMo9-10 steel. Solid State Phenomena. 2013. vol. 202-204, pp. 121-124.

[24] GWOŹDZIK, Monika and NITKIEWICZ, Zygmunt. Studies on the adhesion of oxide layer formed on X10CrMoVNb9-1 steel. Archives of Civil and Mechanical Engineering. 2014. vol. 14, no. 3, pp. 335-341.

[25] GWOŹDZIK, Monika. Analysis of crystallite size changes in an oxide layer formed on steel used in the power industry. Acta Physica Polonica A. 2016. vol. 130, no. 4, pp. 935-938.

[26] GOYAL, Khushdeep, SINGH, Hazoor and BHATIA, Rakesh. Cyclic high temperature corrosion studies of carbon nanotubes- $\mathrm{Cr}_{2} \mathrm{O}_{3}$ composite coatings on boiler steel at $900{ }^{\circ} \mathrm{C}$ in molten salt environment. Anti-Corrosion Methods and Materials. 2018. vol. 65, no. 6, pp. 646-657.

[27] GWOŹDZIK, Monika, KULESZA, Sławomir and BRAMOWICZ, Mirosław. Application of the fractal geometry methods for analysis of oxide layer. In METAL 2017: 26th International Conference on Metallurgy and Materials. Ostrava: TANGER, 2017, pp. 789-794.

[28] GRUBER, Thomas, RETSCHITZEGGER, Stefan, SCHARLER, Robert and OBERNBERGER, Ingwald. Dominating high temperature corrosion mechanisms in low alloy steels in wood chips fired boilers. Energy \& Fuels. 2016. vol. 30, no. 3, pp. 2385-2394.

[29] RETSCHITZEGGER, Stefan, GRUBER, Thomas, BRUNNER, Thomas and OBERNBERGER, Ingwald. Short term online corrosion measurements in biomass fired boilers. Part 2: Investigation of the corrosion behavior of three selected superheater steels for two biomass fuels. Fuel Processing Technology. 2016. vol. 142, pp. 59-70.

[30] GRUBER, Thomas, SCHARLER, Robert and OBERNBERGER, Ingwald. Application of an empirical model in CFD simulations to predict the local high temperature corrosion potential in biomass fired boilers. Biomass \& Bioenergy. 2015. vol. 79, pp. 145-154.

[31] GRUBER, Thomas, SCHULZE, Kai, SCHARLER, Robert and OBERNBERGER, Ingwald. Investigation of the corrosion behaviour of $13 \mathrm{CrMo} 4-5$ for biomass fired boilers with coupled online corrosion and deposit probe measurements. Fuel. 2015. vol. 144, pp. 15-24.

[32] GWOŹDZIK, Monika. Characterization of oxide layers formed on 13CrMo4-5 steel operated for a long time at an elevated temperature. Archives of Metallurgy and Materials. 2015. vol. 60, no. 3, pp. 1783-1788. 